\title{
Egg quality during storage and deposition of minerals in eggs from quails fed diets supplemented with organic selenium, zinc and manganese ${ }^{1}$
}

\author{
Rodrigo Antonio Gravena 2,3, Rafael Henrique Marques ${ }^{2,3}$, Josiane Roccon², Juliana \\ Picarelli ${ }^{2}$, Fabricio Hirota Hada ${ }^{2}$, Janaina Della Torre da Silva ${ }^{2}$, Sandra Aidar de Queiroz ${ }^{2}$, \\ Vera Maria Barbosa de Moraes ${ }^{2,4}$
}

\author{
1 Project funded by Fapesp. \\ 2 Departamento de Zootecnia da Faculdade de Ciências Agrárias e Veterinárias de Jaboticabal (UNESP). \\ 3 Scholar from Fapesp. \\ ${ }^{4}$ Scholar from CNPq.
}

\begin{abstract}
Three experiments with Japanese laying quails were performed aiming to assess the effect of supplementation with minerals in organic form on the egg quality during storage and the deposition of minerals in eggs. The assessments of each experiment were related to one mineral, thus, experiment 1 assessed the supplementation with selenium in 0.35-, 0.70and $1.05-\mathrm{mg} / \mathrm{kg}$ levels of feed; experiment 2, the supplementation with zinc in 50-, 100- and 150-mg/kg levels of feed; and experiment 3, the supplementation of manganese with 60-; 120- and 180-mg/kg levels of feed. All diets were evaluated compared with a control diet without mineral supplementation. Birds were distributed in a completely randomized experimental design, with eight birds per plot and six replicates per treatment. Fifty-five days after the beginning of diets, the yolks of three eggs from each plot were collected for selenium, zinc and manganese quantification, whereas the albumens of three eggs from each parcel were collected for analysis of selenium concentration. Eggs were collected at the last days of the experimental period from each experiment, to be stored at room temperature $\left(28 \pm 2{ }^{\circ} \mathrm{C}\right)$ and refrigeration $\left(4{ }^{\circ} \mathrm{C}\right)$ during different periods (0, 10, 20 and 30 days), except for experiment 3, in which eggs were stored at 0, 10 and 20 days. Percentages of albumen and yolk, yolk index, Haugh unit and moisture loss of eggs were evaluated. The supplementation with selenium is able to maintain the egg yolk index unchanged over the storage periods; however, supplementation with zinc and manganese is not effective to keep the quality of stored eggs. Supplementation with selenium and manganese is effective to increase the concentration of these minerals at $328.66 \%$ in the albumen and at $74.47 \%$ in the yolk, respectively. The different levels of zinc do not change the egg composition.
\end{abstract}

Key Words: antioxidants, Coturnix coturnix japonica, enrichment of eggs, Japanese quail, organic minerals

\section{Introduction}

Among the several functions of selenium (Se) in animals, the main one is the antioxidant role, helping to prevent damages caused by free radicals. This protection occurs due to the enzyme glutathione peroxidase (GSH - Px) and other selenoproteins in the form of selenocysteine (Schrauzer et al., 1980). According to Pappas et al. (2005) and Gajcevic et al. (2009), selenium, supplemented in diets for laying birds, is able to keep good values of Haugh unit for commercial eggs when stored. In addition, selenium can be incorporated into eggs through dietary supplementation of egg-laying hens, especially when supplied in the organic form, which is more efficient than the inorganic form (Payne et al. 2005; Utterback et al., 2005, Bennett \& Cheng, 2010). Breeding birds fed diets supplemented with organic selenium provides eggs with increased concentration of that mineral (Osman et al., 2010).
The functions of zinc ( $\mathrm{Zn})$ and manganese (Mn) are related to eggshell quality (Leeson \& Summers, 2001). Yildiz et al. (2006) observed that Japanese quails receiving diets supplemented with organic zinc produced eggs with thicker eggshells and Mabe et al. (2003) proved that this mineral can be incorporated into eggs through supplementation with the organic form in the diet. Studies with egg-laying hens have demonstrated that supplementation of diet with inorganic manganese increases egg shell thickness (Sazzad et al., 1994). The supply of zinc and manganese in the organic form, rather than inorganic, improved the eggshell resistance (Swiatkiewicz \& Koreleski, 2008) and also, the organic manganese supplied can be incorporated into the eggs (Mabe et al., 2003).

These minerals display several functions in the organism of birds and men, including antioxidant properties with the ability to improve internal and external quality of eggs. Eggs can be enriched with the supplementation of those minerals 
in diets. Based on this premise, this study was conducted to evaluate the effect of dietary supplementation of these minerals in organic form on mineral deposition into quail eggs, and the quality of these eggs when stored at different periods and temperatures, aiming to enhance the nutritional quality of this food.

\section{Material and Methods}

Three experiments were conducted with Japanese quails at laying phase housed in conventional shed for this species with cages placed on stairs, nipple type drinking troughs and continuous galvanized plate feeder, receiving 17 hours of light daily. Birds received supplementation of selenium, zinc and manganese in organic forms, with one experiment for each mineral.

Diets were formulated based on tables of nutrient composition of ingredients proposed by Rostagno et al.(2005) and nutritional requirements according to recommendations by Murakami et al. (1993) and the NRC (1994). Birds from control groups of all the experiments received basal diets with normal levels of selenium, zinc and manganese recommended to meet the requirements of Japanese quails (Table 1).

Basal diets were composed of inorganic sources of selenium, zinc and manganese (sodium selenite, zinc sulfate and manganese sulfate, respectively) and the diets supplemented with selenium, zinc and manganese in organic

Table 1 - Feed composition of the ration supplied to the quails

\begin{tabular}{lc}
\hline Ingredient & $\%$ \\
\hline Corn & 63.507 \\
Soybean meal & 27.622 \\
Dicalcium phosphate & 2.602 \\
Limestone & 4.864 \\
Normal salt (NaCl) & 0.400 \\
Vitamins and mineral supplement ${ }^{1}$ & 0.500 \\
L-lysine (78\%) & 0.336 \\
DL-methionine (98\%) & 0.169 \\
Total & 100 \\
Calculated composition & \\
Crude protein (\%) & 18 \\
Metabolizable energy (kcal/kg) & 2800 \\
Calcium (\%) & 2.50 \\
Available phosphorous (\%) & 0.55 \\
Total lysine (\%) & 1.30 \\
Methionine + total cystine (\%) & 0.76 \\
Selenium (\%) & 0.00003 \\
Zinc (\%) & 0.007 \\
Manganese (\%) & 0.006 \\
\hline
\end{tabular}

${ }^{1}$ Vitamin and mineral supplement (composition/kg feed): folic acid - $0.31 \mathrm{mg}$; biotin - $0.12 \mathrm{mg}$; choline - $300 \mathrm{mg}$; niacin - $12.37 \mathrm{mg}$; pantothenate - $3.56 \mathrm{mg}$; vit. A - 7,812.5 UI; vit. $\mathrm{B}_{1}-1.85 \mathrm{mg}$; vit. $\mathrm{B}_{12}-25$ mcg; vit. $\mathrm{B}_{2}-4.25 \mathrm{mg}$; vit. $\mathrm{B}_{6}$ - $1.23 \mathrm{mg}$; vit. $\mathrm{D}_{3}-3,125 \mathrm{UI}$; vit. E - $15.62 \mathrm{mg}$, vit. K - $1.22 \mathrm{mg}$; copper $9.37 \mathrm{mg}$; iodine - $0.63 \mathrm{mg}$; manganese - $57.18 \mathrm{mg}$; selenium - $0.28 \mathrm{mg}$; zinc $72.28 \mathrm{mg}$; antioxidant $-0.5 \mathrm{mg}$. forms used Sel-Plex ${ }^{\circledR}$ containing $0.1 \%$ of Se, Bioplex ${ }^{\circledR}$ zinc with $15 \%$ of $\mathrm{Zn}$, and Bioplex ${ }^{\circledR}$ manganese with $15 \%$ of $\mathrm{Mn}$, respectively, from Alltech Agroindustrial Ltda company, in Brazil.

Birds from each experiment received the respective diets during 56 days, with 4 laying periods (14 days each) and at the end of the last period, eggs were collected, stored at different temperatures and determined periods and later, minerals were quantified.

The experimental design was completely randomized with 4 treatments, 6 replicates and 8 birds per plot, thus 192 quails at laying phase were used. Experiment 1 comprised the selenium supplementation (control, 0.35, 0.7 and $1.05 \mathrm{mg} / \mathrm{kg}$ of feed), whereas in experiment 2, the supplementation was with zinc (control, 50, 100 and $150 \mathrm{mg} / \mathrm{kg}$ of feed) and experiment 3 used manganese (control, 60, 120 and $180 \mathrm{mg} / \mathrm{kg}$ of feed); all in organic forms. Birds were 10 weeks old in experiments 1 and 2 and 44 weeks old in experiment 3.

Three eggs from each replicate from experiments were collected. Eggs from experiments 1 and 2 were stored during $0,10,20$ and 30 days, whereas the eggs from experiment 3 were stored during 0,10 and 20 days. One group was stored under refrigeration $\left(4^{\circ} \mathrm{C}\right)$ and another under room temperature $\left(28 \pm 2^{\circ} \mathrm{C}\right)$. The eggs to be stored were collected in the last four days of the experiment, in an attempt to reduce some possible influence from the collection periods. At the end of the storage period, eggs were analyzed for evaluation of quality (determined by the percentages of albumen and yolk) yolk index, Haugh unit and moisture loss of eggs.

After the end of the fourth period, i.e., 56 days from the beginning of each experiment, three eggs from each replicate were randomly collected. Three yolks per plot were collected from all experiments, and from experiment 1 , three albumens were also collected. Later, three yolks from each replicate were mixed assembling one single sample, weighted and analyzed for dry matter content, and then frozen at $-20^{\circ} \mathrm{C}$; the same procedures were done with the albumens. Minerals supplemented in diets were quantified in the Departamento de Tecnologia of Faculdade de Ciências Agrárias e Veterinárias de Jaboticabal (UNESP).

Samples were freeze dried at first, and the quantification of the three minerals in eggs began with the mineralization/ digestion of samples, employing oven with microwave radiation. Approximately $0.5 \mathrm{~g}$ of the freeze dried egg sample (yolk or albumen) was added to $3.0 \mathrm{~mL} \mathrm{H}_{2} \mathrm{O}_{2}(30 \%$ ) and $6.0 \mathrm{~mL}$ $\mathrm{HNO}_{3}(65 \%)$ concentrated suprapur (Merck) P.A. and then digestion was simulated in microwave apparatus.

Selenium concentrations were determined by atomic absorption spectrometer equipped with graphite furnace 
module and the background correction was performed by deuterium lamp. The concentrations of zinc and manganese were determined by flame atomic absorption spectrometry (FAAS) using the GBC Avanta device with air-acetylene flame.

The statistical analysis for the quantification of minerals in eggs was the polynomial regression analysis, whereas for the quality of eggs during storage, a $4 \times 4 \times 2$ ( 4 levels of mineral $\times 4$ storage periods $\times 2$ temperatures) factorial arrangement was used, except for experiment 3 , in which the scheme was $4 \times 3 \times 2$. All analyses were performed in SAS statistical software program (Statistical Analysis System, versão 9.1).

\section{Results and Discussion}

Diet supplementation for birds with organic selenium was effective in maintaining the quality of eggs during the periods and conditions of storage evaluated, because the yolk indices (Table 2 ) were better $(\mathrm{P}<0.05)$ when birds were fed diets supplemented with selenium level of $0.35 \mathrm{mg} / \mathrm{kg}$ of feed. This result did not differ $(\mathrm{P}>0.05)$ from those obtained from other levels of supplementation, but it was better than the control group. This ability of selenium to maintain the quality of eggs during storage can be related to increased activity of antioxidant enzymes present in the egg. Other characteristics evaluated were not affected $(\mathrm{P}>0.05)$ by supplementation with organic selenium.
Some results found in the literature were contradictory to those obtained in this study. Pappas et al. (2005) and Gajcevic et al. (2009) concluded that the supplementation of diet for laying hens with selenium in organic form resulted in eggs with higher values of Haugh unit when stored for 0,7 and 14 days and 0,14 and 28 days at room temperature and $4{ }^{\circ} \mathrm{C}$, respectively. However, Mohiti-Asli et al. (2008) did not observe changes in quality of eggs of laying hens with organic selenium supplementation stored during 14 days under different temperatures $\left(4^{\circ} \mathrm{C}, 23-27^{\circ} \mathrm{C}\right.$ and $\left.31^{\circ} \mathrm{C}\right)$.

For every quality trait of eggs evaluated during storage periods, there were interactions $(\mathrm{P}<0.0001)$, except for weight loss, between time and temperature. When slicing these interactions (Figure 1), quality of eggs worsened according to the storage period at room temperature; however, when at refrigerated temperature, the quality was maintained.

There was interaction $(\mathrm{P}<0.05)$ between levels of selenium and storage period for weight loss of eggs (Table 3). After 10 days of storage, the level of selenium of $1.05 \mathrm{mg} / \mathrm{kg}$ of feed increased weight loss of eggs $(\mathrm{P}<0.01)$ when compared with the level of $0.70 \mathrm{mg} / \mathrm{kg}$, but none differed from other levels. Within other periods of storage there was no effect ( $P>0.05$ ) of the levels of selenium on weight loss of eggs.

Sanchez et al. (2009) evaluated the quality of quail eggs stored at three temperatures ( 3 to $5 ; 19$ to 23 and $32^{\circ} \mathrm{C}$ ) during $10,20,30,40,50$ and 60 days of storage and observed weight loss and deterioration of internal quality, concluding that eggs stored for longer periods should be kept at about $4{ }^{\circ} \mathrm{C}$.

Table 2 - Quality of eggs from quails fed diets supplemented with organic selenium, stored at different temperatures and periods

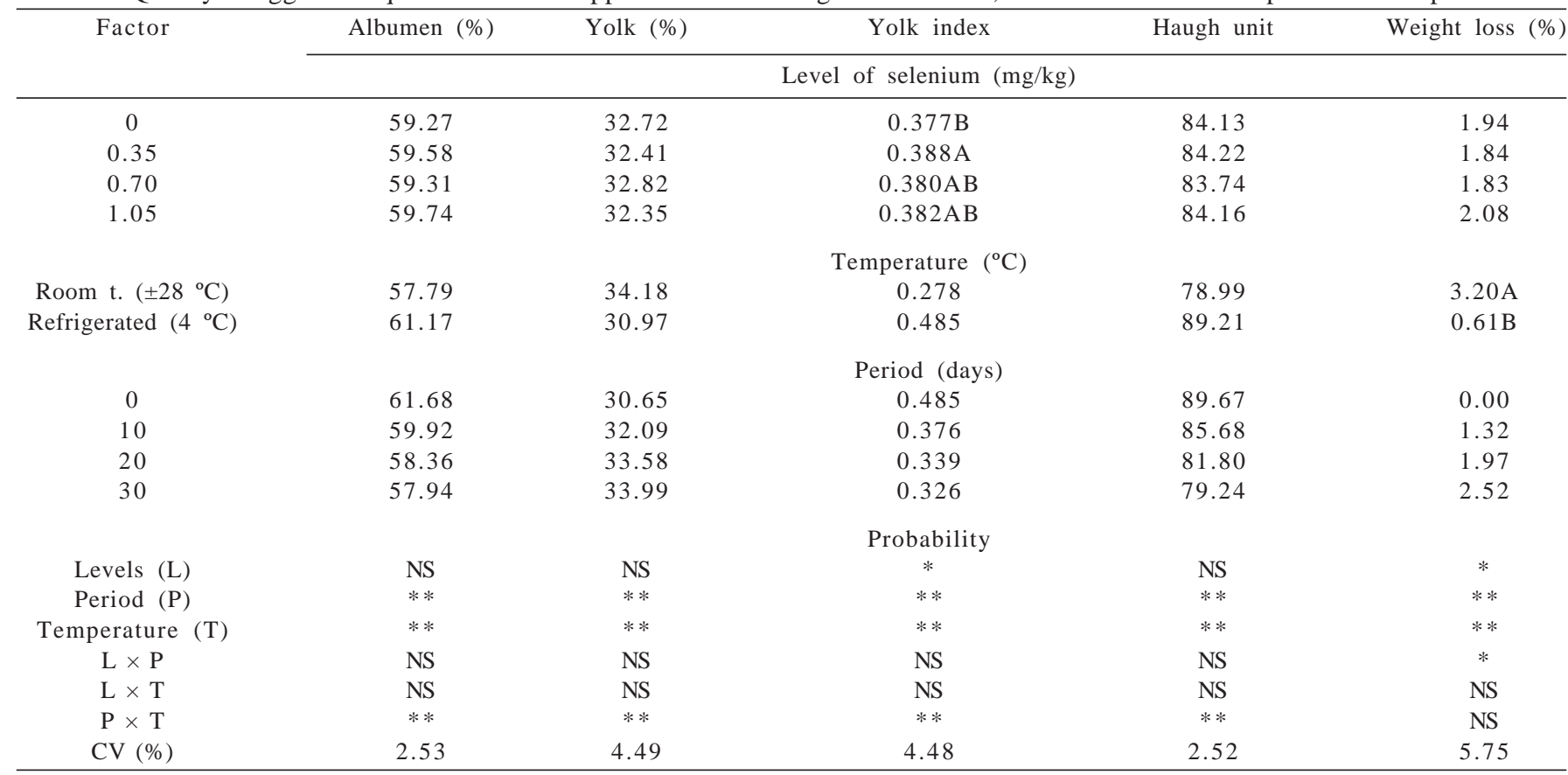

Means followed by different letters in the same column are significantly different by Tukey test $(5 \%)$. $* * P<0.0001 ; * \mathrm{P}<0.05 ; \mathrm{NS}=$ not significant. Data from PP was analyzed after transformation according to equation $\mathrm{PP}=\mathrm{PP} \wedge(1-1.50 / 2)$; however, the present means correspond to the originals. 

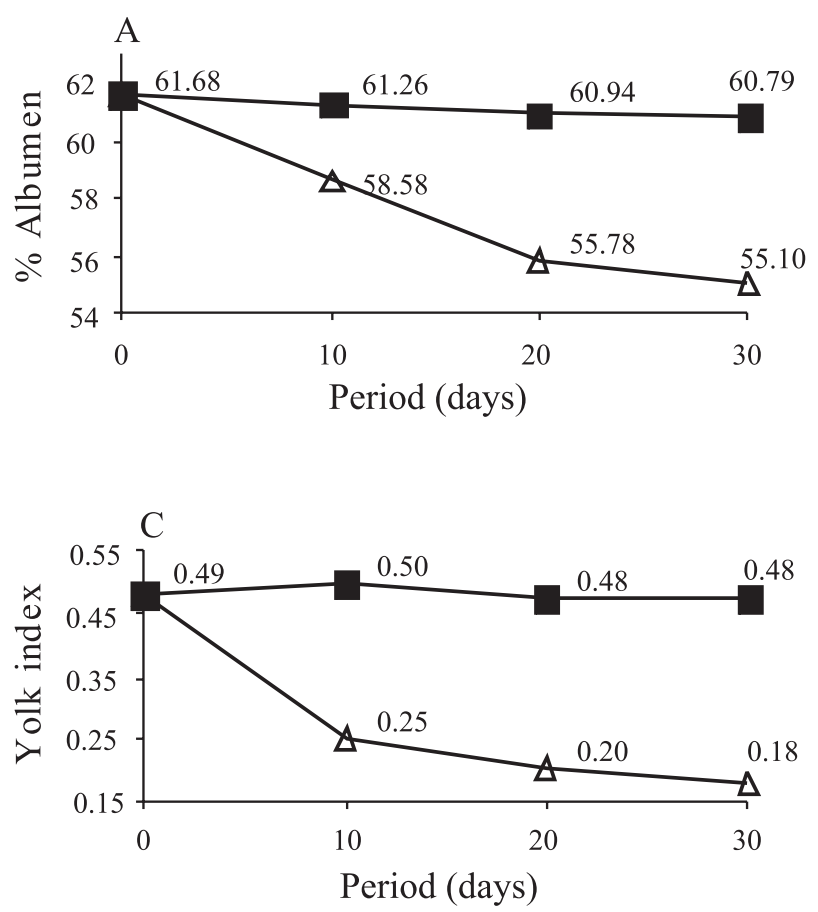

$\neg-$ Room temperature
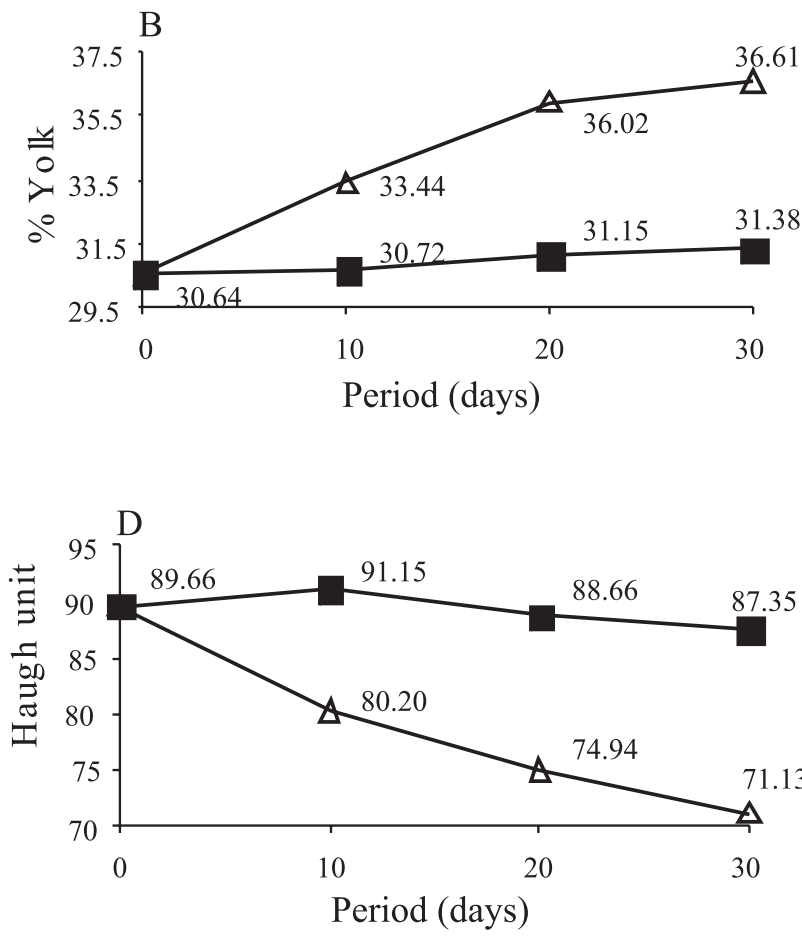

$\longrightarrow$ - Refrigerated temperature

Figure 1 - Means of slicing interactions of traits: percentage of albumen (A) and yolk (B), yolk index (C) and Haugh unit (D) of eggs from quails under supplementation with organic selenium in diet.

Table 3 - Weight loss of quail eggs in each level of selenium and storage period, in percentage

\begin{tabular}{|c|c|c|c|c|c|}
\hline \multirow[t]{2}{*}{ Level of selenium (mg/kg of feed) } & \multicolumn{4}{|c|}{ Period (days) } & \multirow[t]{2}{*}{ Probability } \\
\hline & 0 & 10 & 20 & 30 & \\
\hline 0 & - & $1.28 \mathrm{ABa}$ & $2.19 \mathrm{Ab}$ & $2.54 \mathrm{Ab}$ & * \\
\hline 0.70 & - & $1.02 \mathrm{BCa}$ & $1.96 \mathrm{Ab}$ & $2.37 \mathrm{Ab}$ & * \\
\hline 1.05 & - & 1.61Aa & $1.83 \mathrm{Aa}$ & $2.71 \mathrm{Ab}$ & * \\
\hline Probability & - & $*$ & NS & NS & \\
\hline
\end{tabular}

Means followed by same letters, uppercase in columns and lowercase in the rows, do not differ by Tukey test $(5 \%)$. $\mathrm{P}<0.01$, NS $=$ not significant. Data from PP was analyzed after transformation according to the equation $(\mathrm{PP}=\mathrm{PP} \wedge(1-1.50 / 2)$; however, the present means correspond to the originals.

Results from this study partially agree with those reported by Skrivan et al. (2006), Surai et al. (2006) and Gajcevic et al. (2009) and Kralik et al. (2009); however, supplementation of diet with selenium was able to linearly increase $\left(y=3.09308+9.63459 x, r^{2}=0.52\right)$ the concentration of this mineral only in the albumen (Table 4). This fact can be explained by the selenomethionine role on protein synthesis and protein deposition in this portion of the egg. These results partially agree with those found by Surai et al. (2006), who observed an increase of selenium content in albumen and yolk of eggs from quails supplied with selenium on the level of $0.5 \mathrm{mg} / \mathrm{kg}$ in the diet.
The transfer of selenium to albumen and yolk of eggs from laying hens has already been proved. Payne et al. (2005) and Utterback et al. (2005) verified higher deposition of this mineral in eggs from birds under supplementation with the organic form when compared with inorganic form. Skrivan et al. (2005), Gajcevic et al. (2009), Kralik et al. (2009) and Bennett \& Cheng (2010) observed higher deposition of selenium in albumen than yolk of commercial eggs with the supplementation of organic selenium in diet.

Percentages of yolk and albumen were not modified by the supplementation of the diet from birds with organic zinc, as well as the values of Haugh unit and yolk index (Table 5). 
Results from this study were similar to those observed by Trava et al. (2009), and the values of Haugh unit and yolk index from quail eggs did not change during storage periods 0,10 and 20 days at room and refrigerated temperature with supplementation of organic zinc in diet.

Weight loss of eggs during storage was higher in eggs from birds under organic zinc supplementation on levels of 50 and $100 \mathrm{mg} / \mathrm{kg}$ of feed and stored at room temperature, This fact indicates that the quality of the egg shell was impaired with these levels of supplementation and that storage at room temperature favored the loss of water (Table 6).

Every quality trait of eggs evaluated during storage presented interactions $(\mathrm{P}<0.0001)$ between period and temperature. When slicing these interactions (Figure 2), egg quality worsened as the storage period increased at room temperature and quality was maintained at refrigerated temperature.
Zinc supplementation was unable to increase the concentration of this mineral in yolk $(\mathrm{y}=23.91683-0.27480 \mathrm{x}$ $\left.+0.00419 x^{2}-0.0000161 x^{3}, r^{2}=0.46\right)$ (Table 7). The inefficiency of zinc deposition into eggs when supplied in inorganic form was demonstrated by Skrivan et al. (2005), who supplemented the diet for laying hens with inorganic zinc and did not observe any increase of concentration of this mineral in yolk and albumen. In contrast, Mabe et al. (2003) observed an increase in zinc concentration in yolk of eggs from laying hens that received supplementation of 30 and 60 ppm of organic zinc in diet.

Supplementation of diet for birds with $180 \mathrm{mg} / \mathrm{kg}$ organic manganese increased weight loss of eggs when compared with the control treatment and did not differ from other treatments; however, this fact did not impair the other egg quality traits evaluated, which also were not affected by the levels of organic manganese (Table 8). A hypothesis for the observation of these results may be the higher level of mineral

Table 4 - Concentration of selenium in yolk and albumen on eggs from quails supplemented with organic selenium

\begin{tabular}{cccc}
\hline Level of selenium $(\mathrm{mg} / \mathrm{kg}$ of feed) & \multicolumn{2}{c}{ Selenium concentration } & Incorporation of selenium in albumen (\%) \\
\cline { 2 - 3 } & Yolk $(\mu \mathrm{g} / \mathrm{kg}$ of yolk) & Albumen $(\mu \mathrm{g} / \mathrm{kg}$ of albumen) & - \\
\hline 0 & 68.60 & 3.07 & 110.75 \\
0.35 & 89.27 & 6.47 & 222.47 \\
0.70 & 67.25 & 9.90 & 328.66 \\
1.05 & 72.41 & 13.16 & - \\
CV $(\%)$ & 25.68 & 46.73 & - \\
F value & 0.09 & 23.51 & - \\
Probability & $0.76^{\mathrm{ns}}$ & $0.0001^{*}$ & \\
\hline
\end{tabular}

$\mathrm{CV}=$ coefficient of variation; ns = not significant $(\mathrm{P}>0.05) ; *$ significant linear regression $(\mathrm{P}<0.05)$

Table 5 - Percentages of albumen and yolk, yolk index, Haugh unit and weight loss of quails supplemented with organic zinc stored at different times and temperatures

\begin{tabular}{|c|c|c|c|c|c|}
\hline \multirow[t]{2}{*}{ Factor } & Albumen (\%) & Yolk (\%) & Yolk index & Haugh unit & Weight loss $(\%)$ \\
\hline & \multicolumn{5}{|c|}{ Level of zinc (mg/kg of feed) } \\
\hline 0 & 60.28 & 31.92 & 0.369 & 82.93 & 1.56 \\
\hline 50 & 59.91 & 32.12 & 0.369 & 83.06 & 1.85 \\
\hline 100 & 59.79 & 32.32 & 0.369 & 83.07 & 1.68 \\
\hline 150 & 59.88 & 32.17 & 0.363 & 82.70 & 1.59 \\
\hline \multicolumn{6}{|l|}{ Temperature $\left({ }^{\circ} \mathrm{C}\right)$} \\
\hline Room t. $\left( \pm 28^{\circ} \mathrm{C}\right)$ & 58.37 & 33.60 & 0.271 & 78.12 & 3.04 \\
\hline Refrigerated $\left(4{ }^{\circ} \mathrm{C}\right)$ & 61.57 & 30.65 & 0.464 & 87.76 & 0.53 \\
\hline \multicolumn{6}{|c|}{ Period (days) } \\
\hline 0 & 61.79 & 30.69 & 0.451 & 85.78 & 0.00 \\
\hline 10 & 59.94 & 32.07 & 0.361 & 84.93 & 1.23 \\
\hline 20 & 59.17 & 32.81 & 0.334 & 81.65 & 1.64 \\
\hline 30 & 58.98 & 32.96 & 0.326 & 79.41 & 2.19 \\
\hline \multicolumn{6}{|c|}{ Probability } \\
\hline Levels of $\mathrm{Zn}(\mathrm{N})$ & NS & NS & NS & NS & $* *$ \\
\hline Period $(\mathrm{P})$ & $* *$ & $* *$ & $* *$ & $* *$ & $* *$ \\
\hline Temperature $(\mathrm{T})$ & $* *$ & $* *$ & $* *$ & $* *$ & $* *$ \\
\hline $\mathrm{N} \times \mathrm{P}$ & NS & NS & NS & NS & NS \\
\hline $\mathrm{N} \times \mathrm{T}$ & NS & NS & NS & NS & $* *$ \\
\hline $\mathrm{P} \times \mathrm{T}$ & $* *$ & $* *$ & $* *$ & $* *$ & $* *$ \\
\hline CV (\%) & 1.89 & 3.61 & 4.47 & 2.22 & 15.28 \\
\hline
\end{tabular}

Means followed by different letters in the same column are significantly different by Tukey test $(5 \%)$. NS $=$ not significant. $* * \mathrm{P}<0.0001, * \mathrm{P}<0.01$. 
Table 6 - Weight loss of quail eggs in each level of zinc and storage temperature

\begin{tabular}{cccc}
\hline Level of zinc $(\mathrm{mg} / \mathrm{kg}$ of feed $)$ & Refrigerated $\left(4{ }^{\circ} \mathrm{C}\right)$ & Room t. $\left( \pm 28{ }^{\circ} \mathrm{C}\right)$ & Probability \\
\hline 0 & $0.63 \mathrm{~b}$ & $2.89 \mathrm{Ba}$ & $3.22 \mathrm{Aa}$ \\
$5 *$ & $0.52 \mathrm{~b}$ & $3.29 \mathrm{Aa}$ & $* *$ \\
100 & $0.52 \mathrm{~b}$ & $2.90 \mathrm{Ba}$ & $* *$ \\
150 & $0.49 \mathrm{~b}$ & $*$ & $*$ \\
Probability & NS & & \\
\hline
\end{tabular}

Means followed by same letters, uppercase in columns and lowercase in the rows, do not differ by Tukey test (5\%). **P $<0.0001 ; * \mathrm{P}<0.01$, NS $=$ not significant.

A

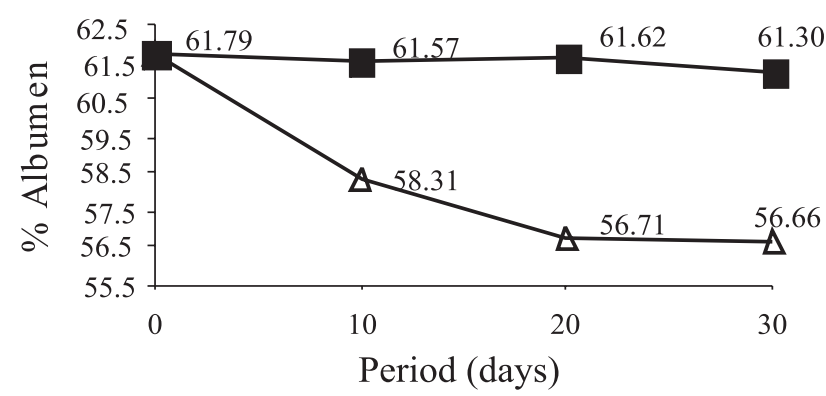

$\mathrm{C}$

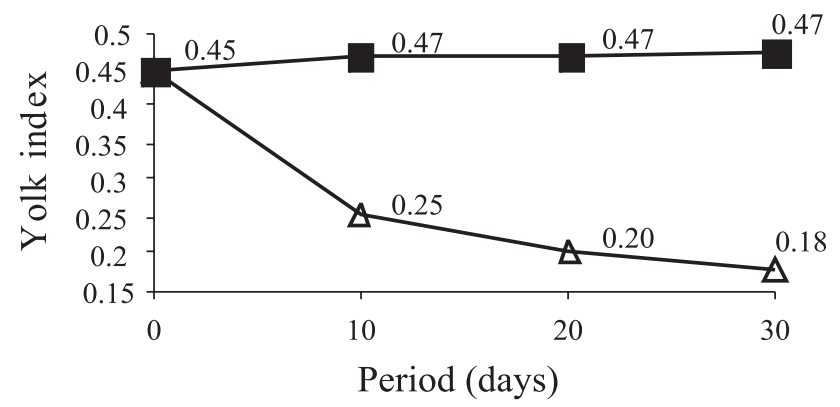

B

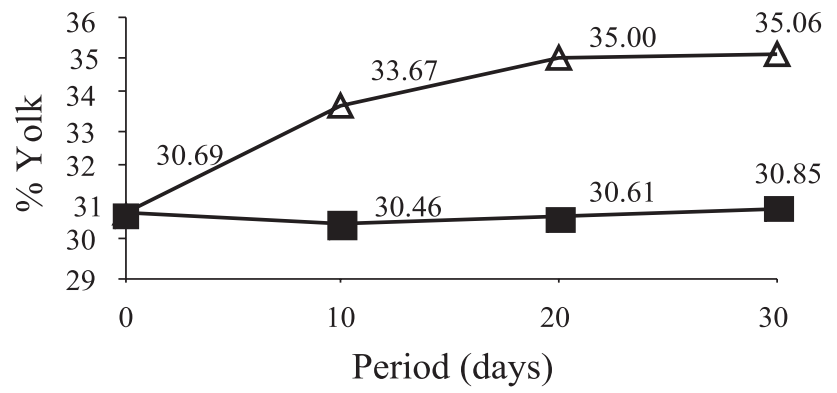

$\mathrm{D}$

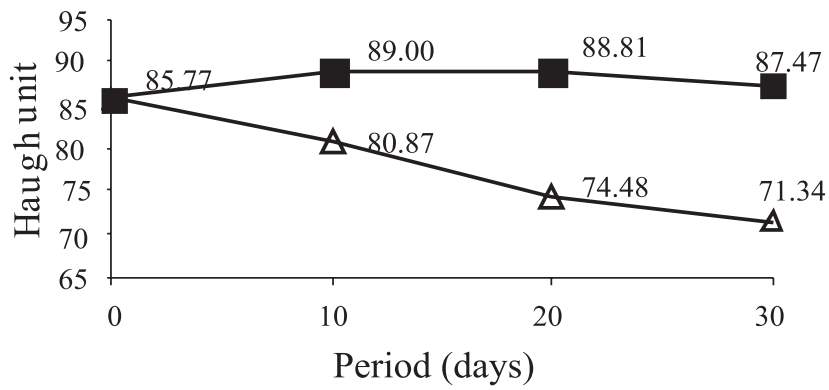

E

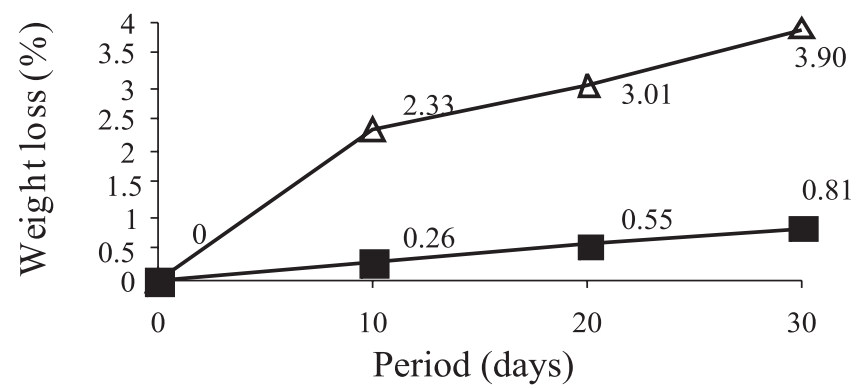

$\neg-$ Room temperature

$\longrightarrow$ - Refrigerated temperature

Figure 2 - Means of slicing interactions of traits: percentage of albumen (A) and yolk (B), yolk index (C) Haug unit (D) and weight loss of eggs from quails under supplementation with organic zinc in diet. 
Table 7 - Means of zinc concentration in yolk of eggs from quails supplemented with organic zinc

\begin{tabular}{cc}
\hline Level of zinc $(\mathrm{mg} / \mathrm{kg}$ of feed) & Concentration of zinc in egg yolks $(\mathrm{mg} / \mathrm{kg}$ of $\mathrm{DM})$ \\
\hline 0 & 23.91 \\
50 & 18.63 \\
100 & 22.22 \\
150 & 22.59 \\
$\mathrm{CV}(\%)$ & 10.59 \\
F value & 5.72 \\
Probability & $0.0054^{*}$ \\
\hline
\end{tabular}

$\overline{\mathrm{DM}}=$ Dry matter; $\mathrm{CV}=$ coefficient of variation; *significant cubic regression $(\mathrm{P}<0.01)$.

Table 8 - Means of percentage of albumen and yolk, yolk index, Haugh unit and weight loss of eggs from quails supplemented with organic manganese stored at different periods and temperatures

\begin{tabular}{|c|c|c|c|c|c|}
\hline \multirow[t]{2}{*}{ Factor } & Albumen (\%) & Yolk (\%) & Yolk index & Haugh unit & Weight loss (\%) \\
\hline & \multicolumn{5}{|c|}{ Level of $\mathrm{Mn}(\mathrm{mg} / \mathrm{kg}$ of feed) } \\
\hline 0 & 59.97 & 32.42 & 0.403 & 83.37 & $2.01 \mathrm{~B}$ \\
\hline 60 & 59.86 & 32.49 & 0.407 & 83.88 & $2.38 \mathrm{AB}$ \\
\hline 120 & 60.02 & 32.32 & 0.405 & 83.16 & $2.33 \mathrm{AB}$ \\
\hline 180 & 59.91 & 32.44 & 0.401 & 83.21 & $2.51 \mathrm{~A}$ \\
\hline & \multicolumn{5}{|c|}{ Temperature $\left({ }^{\circ} \mathrm{C}\right)$} \\
\hline Room t. $\left( \pm 28{ }^{\circ} \mathrm{C}\right)$ & 59.02 & 33.34 & 0.321 & 79.35 & 3.21 \\
\hline Refrigerated $\left(4^{\circ} \mathrm{C}\right)$ & 60.86 & 31.50 & 0.487 & 87.46 & 1.45 \\
\hline \multicolumn{6}{|c|}{ Period (days) } \\
\hline 0 & 60.93 & 31.31 & 0.488 & 89.48 & 0.00 \\
\hline 10 & 60.00 & 32.43 & 0.391 & 82.61 & 2.00 \\
\hline 20 & 58.89 & 33.51 & 0.332 & 78.13 & 2.63 \\
\hline \multicolumn{6}{|c|}{ Probability } \\
\hline Level (L) & NS & NS & NS & NS & $*$ \\
\hline Periods $(\mathrm{P})$ & $* *$ & $* *$ & $* *$ & $* *$ & $* *$ \\
\hline Temperature $(\mathrm{T})$ & $* *$ & $* *$ & $* *$ & $* *$ & $* *$ \\
\hline $\mathrm{L} \times \mathrm{P}$ & NS & NS & NS & NS & NS \\
\hline $\mathrm{L} \times \mathrm{T}$ & NS & NS & NS & NS & NS \\
\hline $\mathrm{P} \times \mathrm{T}$ & $* *$ & $* *$ & $* *$ & $* *$ & $* *$ \\
\hline CV (\%) & 2.10 & 3.79 & 3.70 & 2.84 & 24.42 \\
\hline
\end{tabular}

Means followed by different letters in the same column are significantly different by Tukey test $(5 \%)$. NS $=$ not significant $(\mathrm{P}>0.05)$; ${ }^{*}<0.05 ; * * \mathrm{P}<0.0001$.

supplementation that could have changed some structure of the egg shell, favoring the weight loss of eggs during storage. According to Whisenhunt \& Maurice (1981), a large number of broken eggs was observed when laying hens received high levels of manganese $(800 \mathrm{mg} / \mathrm{kg}$ of feed), although no changes have been observed in egg shell thickness. This fact evidences that the excess of this mineral may change the shell resistance due to possible structural changes.

Weight loss of eggs stored in experiment 3 was higher than in experiments 1 and 2; this fact was related to the age of the birds from experiment 3 , which were older. Thus, the egg shell tends to be thinner and the egg loses more weight during storage, especially at room temperature.

Every quality trait of eggs evaluated during storage presented interactions $(\mathrm{P}<0.0001)$ between period and temperature. When slicing these interactions (Figure 3), the quality of eggs worsened as period of storage increased at room temperature. Nevertheless, the quality was maintained when refrigerated.

Results of manganese concentration in yolk of eggs, expressed in $\mathrm{mg} / \mathrm{kg}$ of yolk (Table 9) proved that the supplementation of diets with organic manganese increased the concentration of this mineral in yolk $(\mathrm{y}=0.46241+$ $\left.0.00176 \mathrm{x}, \mathrm{r}^{2}=0.58\right)$. The model obtained for this trait explained most (58\%) of the variation. The increase of manganese incorporation in yolk reached $74 \%$ with the high level of supplementation.

Results from this study are similar to those obtained by Mabe et al. (2003), who provided diets supplemented with organic and inorganic manganese levels of 0,30 and $60 \mathrm{ppm}$ for laying hens and noticed that birds which received $60 \mathrm{ppm}$ deposited higher level of this mineral in the yolk when compared with the control group. 
A

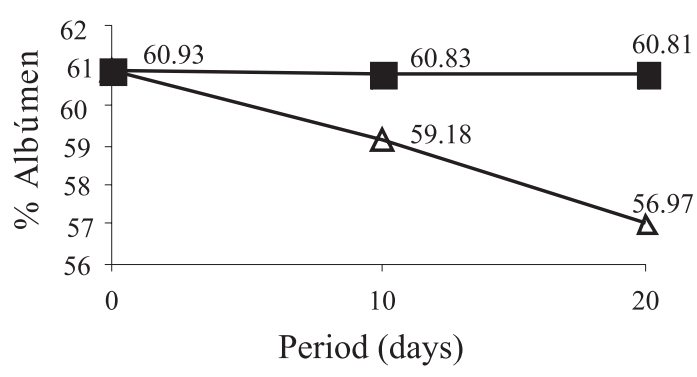

$\mathrm{C}$

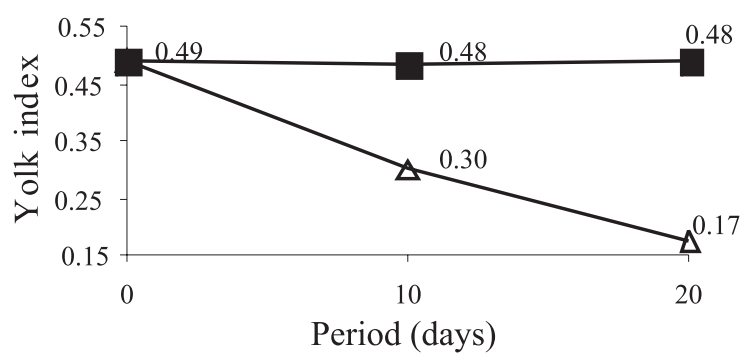

B

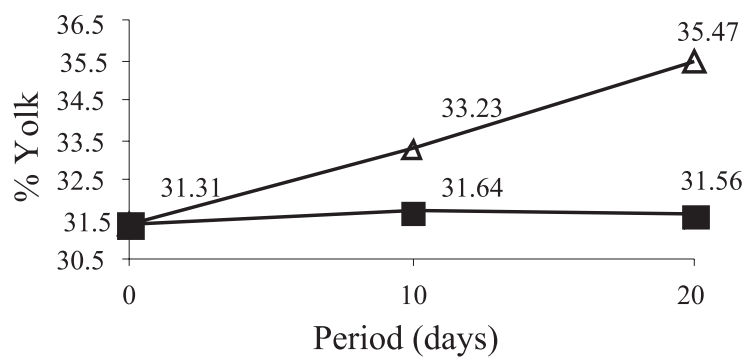

$\mathrm{D}$

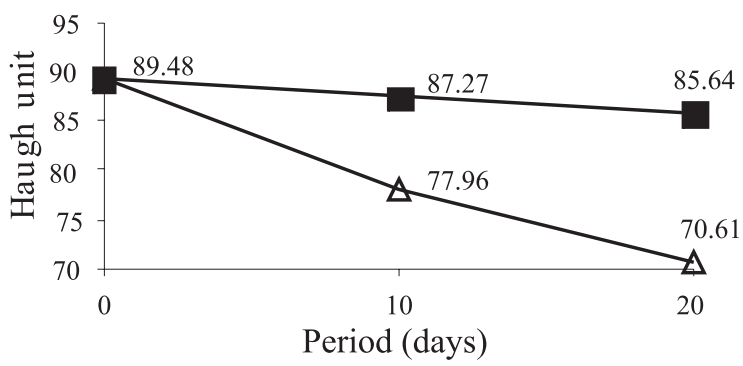

E

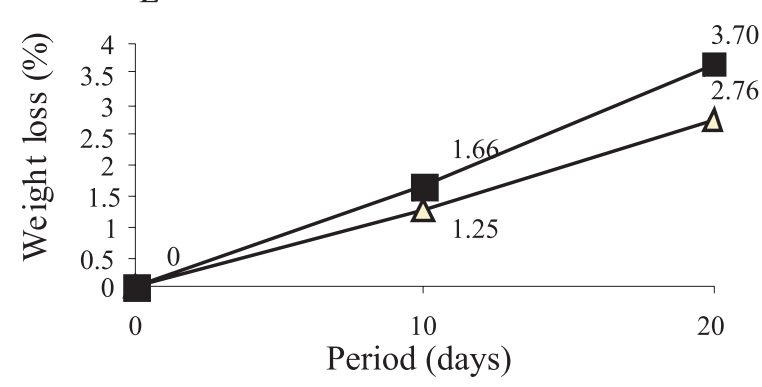

$-\Delta-$ Room temperature

Refrigerated temperature

Figure 3 - Means of slicing interactions of traits: percentage of albumen (A) and yolk (B), yolk index (C) and Haugh unit (D) and weight loss of eggs from quails under supplementation with organic manganese in diet.

Table 9 - Manganese concentration in yolk of eggs from quails supplied with organic manganese

\begin{tabular}{ccc}
\hline Level of $\mathrm{Mn}(\mathrm{mg} / \mathrm{kg}$ of feed) & Concentration of $\mathrm{Mn}$ in yolk $(\mathrm{mg} / \mathrm{kg}$ of yolk) & Incorporation of Mn in yolk $(\%)$ \\
\hline 0 & 0.47 & - \\
60 & 0.59 & 25.53 \\
120 & 0.60 & 74.66 \\
CV $(\%)$ & 0.82 & - \\
F value & 16.85 & - \\
Probability & 30.55 & - \\
\hline
\end{tabular}

$\overline{\mathrm{CV}}=$ coefficient of variation; $*$ significant linear regression $(\mathrm{P}<0.05)$.

\section{Conclusions}

Supplementation with selenium in quail diets delays the quality loss of eggs during storage, and supplementation with selenium and manganese is effective in raising the concentration of these minerals into eggs, enhancing nutritional traits. Therefore, in order to maintain the nutritional quality, eggs must be stored under refrigerated temperature.

\section{Acknowledgements}

We would like to thank Fundação de Amparo à Pesquisa do Estado de São Paulo, for financial support and Master 
degree scholarships and Alltech ${ }^{\circledR}$ animal nutrition and Mr. Osvaldo Esperança Rocha, from VICAMI ${ }^{\circledR}$ Company for donating the quails used in the experiments.

\section{References}

BENNETT, D.C.; CHENG, K.M. Selenium enrichment of table eggs. Poultry Science, v.89, p.2166-2172, 2010.

GAJCEVIC, Z.; KRALIK, G.; HAS-SCHON, E. et al. Effects of organic selenium supplemented to layer diet on table egg freshness and selenium content. Italian Journal of Animal Science, v.8, p.189-199, 2009.

KRALIK, G.; GAJCEVIC, Z.; SUCHY, P. et al. Effects of dietary selenium source and storage on internal quality of eggs. Acta Veterinarian Brunensis, v.78, p.219-222, 2009.

LEESON, S.; SUMMERS, J.D. Nutrition of the chickens. 4.ed. Guelph: University Books, 2001. 591p.

MABE, I.; RAPP, C.; BRAIN, M.M. et al. Supplementation of a corn-soybean diet of manganese, copper, and zinc form organic and inorganic sources improves eggshell quality in aged laying hens. Poultry Science, v.82, p.1903-1913, 2003.

MOHITI-ASLI, M.; SHARIATMADARI, F.; LOTFOLLAHIAN, H. et al. Effects of supplementing layer hen diets with selenium and vitamin $\mathrm{E}$ on egg quality, lipid oxidation and fatty acid composition during storage. Canadian Journal Animal Science, v.88, p.475-483, 2008.

MURAKAMI, A.E.; MORAES, V.M.B.; ARIKI, J. et al. Níveis de proteína e energia em rações para codornas (Coturnix coturnix japonica) em postura. Revista Brasileira de Zootecnia, v.22, n.4, p.541-551, 1993.

NATIONAL RESEARCH COUNCIL - NRC. Nutrient requirements of poultry. 9.ed. Washington, D.C.: National Academy Press, 1994. 155p.

OSMAN, A.M.R.; ABDEL WAHED, H.M.; RAGAB, M.S. Effects of supplementing laying hens diets with organic selenium on egg production, egg quality, fertility and hatchability. Egyptian Poultry Science, v.30, n.3, p.893-915, 2010.

PAPPAS, A.C.; ACAMOVIC, T.; SPARKS, N.H.C. et al. M. Effects of supplementing broiler breeder diets with organic selenium and polyunsaturated fatty acids on egg quality during storage. Poultry Science, v.84, p.865-874, 2005.

PAYNE, R.L.; LAVERGNE, T.K.; SOUTHERN, L.L. Effect of inorganic versus organic selenium on hen production and egg selenium concentration. Poultry Science, v.84, p.232-237, 2005.
ROSTAGNO, H.S.; ALBINO, L.F.T.; DONZELE, J.L. et al. Tabelas brasileiras para aves e suínos: composição de alimentos e exigências nutricionais. 2.ed. Viçosa, MG: UFV, 2005. 186p.

SANCHEZ, J.F.G.; RAMIREZ, F.H.C.; UNZON, H.H. Physicochemical change in quail eggs (Coturnix coturnix japonica) after storage at different temperatures. Journal of Applied Animal Research, v.35, p.177-180, 2009.

SAZZAD, H.M.; BERTECHINI, A.G.; NOBRE, P.T.C. Egg production, tissue deposition and mineral metabolism in two strains of commercial layers with various level of manganese in diet. Animal Feed Science and Technology, v.46, n.3-4, p.271-275, 1994

SCHRAUZER, G.N.; MCGUINNESS, J.E.; KUEHN, K. Effects of temporary selenium supplementation on the genesis of mammary tumors in female inbred C3H/St mice. Carcinogenesis, v.1, p.199, 1980

SKRIVAN, M.; SKRIVANOVA, V.; MAROUNEK, M. Effects of dietary zinc, iron and cooper in layer feed on distribution of these elements in eggs, liver, excreta, soil, and herbage. Poultry Science, v.84, p.1570-1575, 2005.

SKRIVAN, M.; SIMÁNE, J.; DLOUHÁ, G. et al. Effect of dietary sodium selenite, Se-enriched yeast and Se-enriched Chlorella on egg Se concentration, physical parameters of eggs and laying hens production. Czech Journal Animal Science, v.51, n.4, p.163-167, 2006.

SURAI, P.F.; KARADAS, F.; PAPPAS, A.C. et al. Effect of organic selenium in quail diet on its accumulation in tissues and transfer to the progeny. British Poultry Science, v.47, p.65-72, 2006.

SWIATKIEWICZ, S.; KORELESKI, J. The effect of zinc and manganese source in the diet for laying hens on eggshell and bones quality. Veterinarni Medicina, v.53, n.10, p.555-563, 2008.

TRAVA, C.M.; FERNANDEZ, I.B.; CRUZ, V.C. et al. Efeito da temperatura e do tempo de armazenamento sobre a qualidade interna de ovos de codornas submetidas a dietas com Selênio e Zinco orgânicos. In: REUNIÃO ANUAL DA SOCIEDADE BRASILEIRA DE ZOOTECNIA, 46., 2009, Maringá. Anais... Maringá: Sociedade Brasileira de Zootecnia. 2009.

UTTERBACK, P.L.; PARSONS, C.M.; YOON, I. et al. Effect of supplementing selenium yeast in diets of laying hens on egg selenium content. Poultry Science, v.84, p.1900-1901, 2005.

YILDIZ, N.; ERISIR, Z.; SAHIM, K. et al. Effect of zinc picolinate on the quality of Japanese quail eggs. Journal of Animal and Veterinary Advances, v.5, n.12, p.1181-1184, 2006.

WHISENHUNT, J.E; MAURICE, D.V. The response of egg shell quality to dietary manganese and load. Poultry Science, v.60, n.7, p.1609, 1981. 